\title{
ASEXUAL REPRODUCTION OF NAUSITHOE AUREA (CNIDARIA, SCYPHOZOA, CORONATAE) INDUCED BY STERILE POLYSTYRENE DISHES
}

\author{
Sérgio N. Stampar ${ }^{1}$, Fábio Lang da Silveira ${ }^{1} \&$ André C. Morandini ${ }^{2}$ \\ ${ }^{1}$ Instituto de Biociências da Universidade de São Paulo \\ Laboratório de Cultivo e Estudos de Cnidaria, Departamento de Zoologia, \\ (Rua do Matão, Travessa 14, 101 05508-900 Cidade Universitária, São Paulo, SP, Brasil) \\ ${ }^{2}$ Universidade Federal do Rio de Janeiro \\ Núcleo em Ecologia e Desenvolvimento Sócio-Ambiental de Macaé (NUPEM/UFRJ) \\ Grupo de Pesquisa em Sistemática e Biologia Evolutiva (GSE) \\ (Rua Rotary Club, s/n, CP 119331 São José do Barreto, Macaé, RJ, Brasil) \\ E-mails: stampar@usp.br or sergiostampar@gmail.com
}

Some scyphozoan species have a few peculiarities and these are reflected in their life cycles (e.g. type or seasonality of strobilations) (see more in Berrill, 1949 and Silveira et al., 2003). For the scyphozoan order Coronatae, the solitary polyps are hypothesized to strobilate under conditions of energy surplus, while colonial species tend to strobilate in determined periods (Werner, 1970). The strobilation process of the scyphozoans is a relevant morphological event that helps understanding the evolution and relationships of other taxonomic groups (see more in Berrill, 1949 and Collins et al., 2006). The variety of reproductive traits is very interesting and, unfortunately, quite overlooked in Scyphozoa (see more in Arai, 1997).

Strobilation inducing factors of some solitary scyphozoans are widely known, such as iodine, temperature, light regime and abundance of food (see details in Kroiher et al., 2000). These inducers are able to be tested experimentally, by adding controlled amounts of food or concentrations of iodine, or controlling the variation of temperature and light regime. However, some other factors have not been considered, for example the influence of some objects during the experiment (e.g. forceps, pointers or dishes), as pointed out by the results of Herrmann et al. (2003). The influence of the culturing dishes in the strobilation of the coronate scyphozoan Nausithoe aurea is the focus of this communication.

The species employed in this work was the solitary coronate Nausithoe aurea Silveira \& Morandini, 1997. It is a rather common scyphopolyp species found in southeastern Brazilian coast and there is detailed information on the life cycle, embryonic development and behavior in Silveira \& Morandini, 1997; Morandini \& Silveira, 2001; Silveira et al., 2003; Holst \& Jarms, 2006; Stampar \& Silveira, 2006. In the life cycle of $N$. aurea the strobilation may produce either ephyrae (which grows to mature medusae) or planuloids (Silveira \& Morandini, 1997).

Using the results and the protocol established by Herrmann et al. (2003) we created a protocol to verify the possible strobilation induction by sterile polystyrene dishes in the species Nausithoe aurea. The dishes used in this work were from Corning ${ }^{\circledR}$, series (430165), sizing $35 \mathrm{~mm}$ x $10 \mathrm{~mm}$.

Fifty four polyps were used in the experiment. All polyps were sampled in São Sebastião Channel, the type locality of $N$. aurea. These polyps were divided into three different groups (eighteen polyps in each group divided in 6 dishes of $4 \mathrm{ml}$ with, 3 polyps per dish), as described below:

Group A - Sterile polystyrene dishes, without any previous cleanse.

Group B - Sterile polystyrene dishes, but washed with artificial seawater at $70^{\circ} \mathrm{C}$ by $15 \mathrm{~min}$.

Group C - Polystyrene dishes, washed with HCL (1\%) and artificial seawater at $22^{\circ} \mathrm{C}$ by $15 \mathrm{~min}$.

All experiments were conducted at controlled temperature $\left(22^{\circ} \mathrm{C}\right)$.

The observations on the polyps were performed daily until the conclusion of the experiments (21 days). The artificial seawater (Tropic Marin $\left({ }^{\circledR}\right)$ used in the experiments was changed every week. When a polyp starts to strobilate, it was removed from the experiment to avoid induction of other polyps (Loeb, 1974; Arai, 1997).

The experiments showed two distinct results. In the initial four days, strobilation was not observed (Fig. 1). However, in the fifth day a polyp from experiment $\mathbf{A}$ began the process of strobilation. These results were observed in the following days with up to six strobilating polyps (Fig. 1) only in group A (sterile dishes). The results showed a strobilation ratio of $30 \%$ in the polyps from group A. The two other experimental groups, $\mathbf{B}$ and $\mathbf{C}$, did not present any strobilating polyps. 


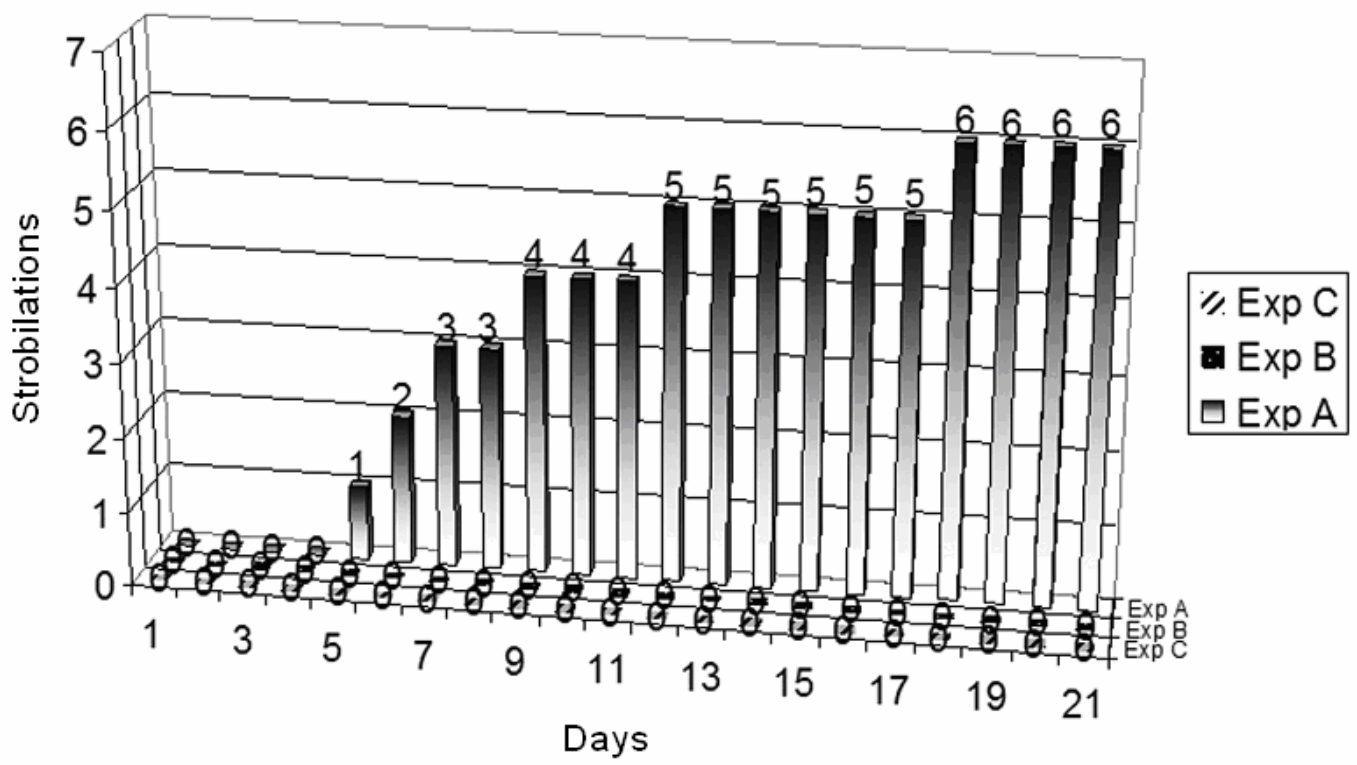

Fig. 1. Strobilation results in 21 days of experiment by group. Legends: Group A - sterile polystyrene dishes; Group B - sterile polystyrene dishes, washed with water at $70^{\circ} \mathrm{C}$ and Group $\mathrm{C}-$ Old dishes (previously used) and washed with $\mathrm{HCL}$ (hydrochloric acid 5\%).

The strobilation results observed by Herrmann et al. (2003) in the scyphozoan Aurelia aurita (Linnaeus, 1758) were greater than ours. However, our results showed the same kind of influence from the sterile polystyrene dishes in the Coronatae species Nausithoe aurea. When we compare the results of the other two groups, $\mathbf{B}$ and $\mathbf{C}$, with those of group $\mathbf{A}$ the differences are clearer. The data were analyzed using the method of inference for stratified categorical data - The Mantel-Haenszel Test $\left(X^{2}{ }_{M H}\right)$. The $X^{2}{ }_{M H}$ value of the experiments is 14.60 . Since $X_{1,999}^{2}=10.83<14.60=X_{M H}^{2}$, it follows that $p$ $<.001$ concluding that we reject the null hypothesis (see more in Rosner, 2000).

The induction of strobilation has been attributed to the use of sterile polystyrene dishes. The cause is probably the formation of Reactive Oxygen Species (ROS) by substances that were used to turn the polystyrene dishes sterile, as pointed out by Herrmann et al. (2003) and Berking et al. (2005).

The fleeting intermediates (chemical compound formed by one reaction and then used in another) produced by radiation and respiration are called free radicals. The use of this term is only a convenience. Not all of these fleeting intermediates are free radicals within the usual definition of the term. Applying the correct terminology, however, is cumbersome. Another umbrella term to these fleeting intermediates, ROS, is even more cumbersome and also untrue - not all are especially reactive and some, such as nitric oxide (NO) are technically reactive nitrogen species (Lane, 2002). However, ROS is a broader expression than free radicals or oxidizing free radicals (Gilbert \& Colton, 1999). ROS is a collective term often used to include not only the oxygen radicals $\left(\mathrm{O}_{2}{ }^{-}\right.$and $\left.\mathrm{OH}\right)$ but also some non-radical derivates of $\mathrm{O}_{2}$ (Halliwell \& Gutteridger, 1999). ROS (as an umbrella term) includes the superoxide radical anion, hydrogen peroxide, the hydroxyl radical, lipid peroxides, the peroxyl radicals, the alkoxy radicals, the radicals of nitric oxide and nitrogen dioxide, ozone and possibly singlet oxygen, either in its low energy form or in its high energy form (Gilbert \& Colton, 1999). In the way of confusion in the terminology we prefer to use ROS, because it is more widespread within academic publications as a broader term.

Constantly, the ROS are built by cellular metabolism from oxidize of NADPH in the major part of cell types so far known (Gretzer et al., 2002). Berking et al. (2005) showed that the addition of $1 \mathrm{nM}$ of Hydrogen Peroxide $\left(\mathrm{H}_{2} \mathrm{O}_{2}\right)$ causes in A. aurita up to $50 \%$ of strobilation. Nevertheless, high concentrations of $\mathrm{H}_{2} \mathrm{O}_{2}$ can result in cell injuries observed as DNA damages, disabling dehydrogenases (Spragg et al., 1987). In addition, the extra-cellular $\mathrm{H}_{2} \mathrm{O}_{2}$ can induce apoptosis processes (Laochumroonvorapong et al., 1996; see more in Gretzer et al., 2002).

When the metabolic demand is low (few or no food is offered), mitochondria come into resting stage (Alberts et al., 2002; Blackstone, 2001). In this period, the phosphorylation is minimal and the electrons cart is much reduced, what can induce the 
ROS production. Subsequently, this way can be an alternative form of reproduction in this species in conditions of low food availability. On the other hand, when a lot of food is available the phosphorylation is greater and the electron cart is very high and the ROS production is low (Blackstone, 2001).

These aspects are still unexplored in cnidarians; a few works referring to this issue and only one concerning a hydrozoan (Blackstone, 2001), a closer group to the scyphozoans. The induction of asexual reproduction (strobilation) by laboratory stuff is a significant issue and this is once more demonstrated in a different cnidarian species. It is very important to pay attention to other modifications that can be caused by use of sterile polystyrene dishes.

\section{AcKnowledgements}

We thank Drs Angélica R. Soares (NUPEM/UFRJ) and Klaus Herrmann (Universität zu Köln) for helpful suggestions in the text. We are grateful to an anonymous reviewer for criticism and helpful suggestions. SNS was supported by a CAPES scholarship through the Post-Graduate Program in Biological Science, Zoology, IBUSP.

\section{REFERENCES}

ALBERTS, B. et al. Molecular biology of the cell. 4. ed. New York : Garland Science, 2002. 1463 p.

ARAI, M. N. A functional biology of Scyphozoa. London: Chapman and Hall, 1997.316 p.

BERKING, S. et al. A newly discovered oxidant defence system and its involvement in the development of Aurelia aurita (Scyphozoa: Cnidaria): reactive oxygen species and elemental iodine control medusa formation. Int. J. Dev. Biol., v. 49, p. 969-976, 2005.

BERRILL, N. J. Developmental analysis of Scyphomedusae. Biol. Rev., v. 24, p. 393-410, 1949

BLACKSTONE, N. W. Redox state, reactive oxygen species and adaptive growth in colonial hydroids. J. expl mar. Biol., v. 204, n. 11, p. 1845-1853, 2001.

COLLINS, A. G. et al. Medusozoan phylogeny and character evolution clarified by new large and small subunit rDNA data and an assessment of the utility of phylogenetic mixture models. Syst. Biol., v. 55, n. 1, p. 97-115, 2006.

GILBERT, D. L.; COLTON, C. A. Reactive oxygen species in biological systems: an interdisciplinary approach. New York: Kluwer Academic, 1999. 707 p.

GRETZER, C. et al. $\mathrm{H}_{2} \mathrm{O}_{2}$ production by cells on titanium and polystyrene surfaces using an in vivo model of exudate and surface related cell function. J. mathl Sci.Math. in Med., v. 13, n. 8, p. 735-743, 2002.
HALLIWELL, B.; GUTTERIDGER, J. M. C. Free radicals in biology and medicine. 3. ed. New York: Oxford Science Publications, 1999. $936 \mathrm{p}$.

HERRMANN, K.; SIEFKER, B.; BERKING, S. Sterile polystyrene culture dishes induce transformation of polyps into medusae in Aurelia aurita (Scyphozoa, Cnidaria). Met. Cell Sci., v. 25, p. 135-136, 2003.

HOLST, S.; JARMS, G. Responses of solitary and colonial coronate polyps (Cnidaria, Scyphozoa, Coronatae) to sedimentation and burial. J.E.M.B.E., v. 329, p. 230238, 2006.

KROIHER, M.; SIEFKER, B.; BERKING, S. Induction of segmentation in polyps of Aurelia aurita (Scyphzoa, Cnidaria) into medusae and formation of mirror-image medusa anlagen. Int. J. Dev. Biol., v. 44, p. 485-490, 2000.

LANE, N. Oxygen : The molecule that made the world. New York: Oxford University, 2002. $374 \mathrm{p}$.

LAOCHUMROONVORAPONG, P. et al. $\mathrm{H}_{2} \mathrm{O}_{2}$ induces monocyte apoptosis and reduces viability of Mycobacterium avium-M. intracellulare within cultured human monocytes. Infect. Immun., v. 64, n. 2, p. 452$459,1996$.

LOEB, M. J. Strobilation in the Chesapeake Bay sea nettle Chrysaora quinquecirrha - III. Dissociation of the neckinducing factor from strobilating polyps. Comp. Biochem. Physiol., v. 49A, p. 423-432, 1974.

MORANDINI, A. C.; SILVEIRA, F. L. Sexual reproduction of Nausithoe aurea (Scyphozoa, Coronatae). Gametogenesis, egg releae, embryonic development, and gastrulation. Sci. Mar., v. 65, n. 2, p. 139-149, 2001.

ROSNER, B. Fundamentals of biostatistics. Pacific Grove, CA: Duxbury, 2000. 792 p.

SILVEIRA, F. L.; MORANDINI, A. C. Nausithoe aurea $\mathrm{n}$. sp. (Scyphozoa: Coronatae: Nausithoidae), a species with two pathways of reproduction after strobilation: sexual and asexual. Contr. Zool., v. 66, n. 4, p. 235-246, 1997.

SILVEIRA, F. L.; MORANDINI, A. C.; JARMS, G. Experiments in nature and laboratory observations with Nausithoe aurea (Scyphozoa: Coronatae) support the concept of perennation by tissue saving and confirm dormancy. Biota Neotr., v. 2, n. 2, p. 1-25, 2003.

SPRAGG, R. G. et al. Oxidant injury of cultured cells: biochemical consequences. Prog. Clin. Biol. Res., v. 236A, p. 253-258, 1987.

STAMPAR, S. N.; SILVEIRA, F. L. The survival of Nausithoe aurea Silveira; Morandini, 1997 (Cnidaria, Scyphozoa, Coronatae) under extended period of starvation. Invest. Mar., v. 34, n. 2, p. 120-127, 2006.

WERNER, B. Contribution to the evolution in the genus Stephanocyphus (Scyphozoa, Coronatae) and ecology and regeneration qualities of Stephanocyphus racemosus. Publ. Seto mar. biol. Lab., v. 18, n. 1, p. 1-20, 1970.

(Manuscript received 25 November 2006; revised 16 April 2007; accepted 04 May 2007) 